\title{
PENGARUH KOMPETENSI, MOTIVASI, BUDAYA PERUSAHAAN TERHADAP KINERJA KARYAWAN POLITEKNIK SWASTA DI BANDUNG
}

\author{
Priatna Kesumah $^{1}$; Dematria Pringgabayu ${ }^{2}$ \\ ${ }^{1,2}$ Politeknik Pajajaran ICB Bandung \\ E-mail : dematria.pringgabayu@ @oljan.ac.id
}

\begin{abstract}
The purpose of this study to determine: 1) Competence, Motivation, Corporate Culture and Performance of Employees in the Private-owned Politechnic; 2) to determine the effect of Competence on Employee Performance, 3) to determine the effect of motivation on employee performance; 4) to determine the effect of Company Culture Employee Performance; 5) to determine the effect of Competence, Motivation and the Culture Company simultaneously on Employee Performance Private-owned Politechnic. The method is a method of research used census (population) of 121 respondents using descriptive analysis and verifikatif.From the results of descriptive analysis showed that the total effect of Competency (X1) of the Employee Performance (Y) of 26.16\%, the total effect of motivation (X2) of the Employee Performance (Y) of 32.40\%, and the total effect of Work Culture (X3) Performance of Employees ( $\mathrm{Y}$ ) of $25.22 \%$. While the influence of Competence, Motivation, Corporate Culture of Performance jointly or simultaneously have the effect of a total of $83.79 \%$.
\end{abstract}

Keywords: Competence, Motivation, Corporate Culture and Employee Performance

\section{PENDAHULUAN}

Pengelolaan SDM di Perguruan Tinggi berbeda dengan pengelolaan SDM di perusahaan, karena karakteristik organisasi Perguruan Tinggi yang berbeda dengan perusahaan. Perguruan Tinggi memiliki tiga misi utama, yaitu pendidikan, penelitian dan pengabdian masyarakat. Dari ketiga misi ini, Perguruan Tinggi diharapkan mampu berkontribusi optimal terhadap pembangunan di suatu negara, dalam berbagai aspek. Selain itu, Perguruan Tinggi juga memiliki misi sosial untuk mencerdaskan kehidupan bangsa, memberdayakan masyarakat, berkontribusi terhadap penyelesaian masalah di masyarakat.

Politeknik Swasta yang berlokasi di Bandung, saat ini memiliki pegawai sejumlah 32 orang untuk mengelola 4 bidang kerja: bidang akademik, bidang administrasi umum dan keuangan, bidang kemahasiswaan, bidang kerjasama dan marketing. Dengan jumlah total mahasiswa yang ditangani sebanyak 289, secara kualitas dengan beban kerja yang harus dikerjakan, jumlah karyawan masih kurang, khusunya untuk karyawan yang mempunyai kualifikasi yang dibutuhkan. Sementara itu tuntutan untuk memberikan pelayanan prima kepada setiap civitas akademika (mahasiswa) dituntut tersedianya SDM yang memiliki kompetensi yang prima, namun pengkayaan (pengembangan) kompetensi dengan memberikan pelatihan kepada setiap SDM diamati sangat minim sekali dilakukan oleh Politeknik Swasta.

Begitu pula dengan pengembangan karir dan prestasi jarang direncanakan secara sistematis, sehingga seringkali hanya berkembang secara acak dan konsekuensinya pengembangan karir dan prestasi sering tidak menempatkan sumberdaya manusia sesuai dengan kemampuannya. Akhirnya tujuan instiusi maupun individu sulit atau bahkan tidak dapat tercapai. 
Secara internal, masalah yang dihadapi adalah tingkat kehadiran karyawan Politeknik Swasta cukup rendah, begitu juga tingkat keterlambatannya cukup tinggi yang penulis asumsikan tingkat motivasi mereka terhadap pekerjaan karyawan di Politeknik Swasta cukup rendah.

Disamping itu, dari observasi lapangan, kesungguhan karyawan Politeknik Swasta dalam mematuhi budaya organisasi dirasakan relatif belum maksimal. Indikasinya dapat dilihat banyak karyawan tidak disiplin dalam mengajukan ijin tidak bekerja, tidak mentaati waktu masuk maupun istirahat dan waktu pulang, dan tidak semuanya menggunakan seragam kerja, dan ada gap kelompok, dengan demikian dapat di asumsikan bahwa budaya organisasi yang ada masih belum optimal.

Selain itu sebagian besar penerimaan karyawan tidak linier dengan bidang pekerjaan, sehingga banyak intelektual pendidikan tetapi tidak sesuai dengan kompetensi kerja. Dari data ini menunjukkan bahwa kompetensi ditinjau dari segi pengetahuan adalah sangat rendah.

\section{TINJAUAN PUSTAKA}

Terdapat banyak pengertian yang diberikan oleh para penulis tentang motivasi. Di antaranya adalah Robert Heller dalam Wibowo, 2014 : 109, yang menyatakan bahwa motivasi adalah keinginan untuk bertindak. Setiap orang dapat termotivasi oleh beberapa kekuatan yang berbeda. Di pekerjaan, kita perlu memengaruhi bawahan untuk menyelaraskan motivasinya dengan kebutuhan organisasi.

Motivasi kerja adalah hasil dari kumpulan kekuatan internal dan eksternal yang menyebabkan pekerja memilih jalan bertindak yang sesuai dan menggunakan perilaku tertentu. Idealnya, perilaku ini akan diarahkan pada pencapaian tujuan organisasi (Newstrom dalam Wibowo, 2014 : 110). Sementara itu Newstrom mengemukakan bahwa sebagai indikator motivasi adalah : Engagement. Engagement merupakan janji pekerja untuk menunjukkan tingkat antusiasme, inisiatif, dan usaha untuk meneruskan. Commitment. Komitmen adalah suatu tingkatan dimana pekerja mengikat dengan organisasi dan menunjukkan tindakan organizational citizenship. Satisfaction. Kepuasan merupakan refleksi pemenuhan kontrak psikologis dan memenuhi harapan di tempat kerja. Turnover. Turnover merupakan kehilangan pekerja yang dihargai.

Budaya organisasi menurut Stephen P. Robbins dalam Wibowo (2013 : 17) adalah sebuah persepsi umum yang dipegang oleh anggota organisasi, suatu sistem tentang keberartian bersama. Budaya organisasi berkepentingan dengan bagaimana pekerja merasakan karakteristik suatu budaya organisasi, tidak dengan apakah seperti mereka atau tidak.

Sementara itu, James L. Gibson, John M. Ivancevich, dan James $H$. Donnelly, Jr. dalam Wibowo (2013 : 17) memberikan pengertian budaya organisasi sebagai apa yang dirasakan pekerja dan bagaimana persepsi ini menciptakan pola keyakinan, nilai-nilai, dan harapan.

Adapun menurut Robert Kreitner dan Angelo Kinicki dalam Wibowo (2013 : 17), budaya organisasi adalah nilai-nilai dan keyakinan bersama yang mendasari identitas perusahaan. Definisi Kreitner dan Kinicki ini menunjukkan tiga karakteristik penting budaya organisasi, yaitu : (1) budaya organisasi diteruskan kepada pekerja baru melalui proses sosialisasi, (2) budaya organisasi memengaruhi perilaku kita di pekerjaan, dan (3) budaya organisasi bekerja pada dua tingkatan yang berbeda.

Menurut Jerald Greenberg dan Robert A. Baron dalam Wibowo (2013 : 


\section{Jurnal Ilmiah Ekonomi dan Bisnis}

Vol. 15. No.1, Maret 2018: 78-83

EISSN : $2442-9813$

17) menyatakan budaya organisasi sebagai kerangka kerja kognitif yang terdiri dari sikap, nilai-nilai, norma perilaku dan harapan yang diterima bersama oleh anggota organisasi. Akar setiap budaya organisasi adalah serangkaian karakteristik inti yang dihargai secara kolektif oleh anggota organisasi.

Ada banyak pengertian atau definisi tentang kompetensi dari berbagai ahli, diantaranya adalah sebagai berikut. Menurut Richard E. Boyatzis (Sudarmanto, 2014 : 46), kompetensi adalah karakteristikkarakteristik yang berhubungan dengan kinerja unggul dan atau efektif di dalam pekerjaan.

Menurut Lyle Spencer \& Signe Spencer (Sudarmanto, 2014 : 46), kompetensi merupakan karakteristik dasar perilaku individu yang berhubungan dengan kriteria acuan efektif dan atau kinerja unggul di dalam pekerjaan atau situasi. Menurut Michael Armstrong (Sudarmanto, 2014 : 46), kompetensi adalah apa yang orang bawa pada suatu pekerjaan dalam bentuk tipe dan tingkat-tingkat perilaku yang berbeda-beda. Kompetensi menentukan aspek-aspek proses kinerja pekerjaan.

Brian E. Becher, Mark Huslid \& Dave Ulrich (Sudarmanto, 2014 : 47) mendefinisikan kompetensi sebagai pengetahuan keahlian, kemampuan, atau karakteristik pribadi individu yang memengaruhi secara langsung kinerja pekerjaan.

Badan Kepegawaian Negara (Sudarmanto, 2014 : 49), mendefinisikan kompetensi sebagai kemampuan dan karakteristik yang dimiliki seorang Pegawai Negeri Sipil yang berupa pengetahuan, keterampilan, dan sikap perilaku yang diperlukan dalam pelaksanaan tugas jabatannya, sehingga Pegawai Negeri Sipil tersebut dapat melaksanakan tugasnya secara professional, efektif, dan efisien
Kinerja merujuk pengertian sebagai hasil. Dalam konteks hasil, Bernardin (Sudarmanto, 2014 : 8) menyatakan bahwa kinerja merupakan catatan hasil yang diproduksi (dihasilkan) atas fungsi pekerjaan tertentu atau aktivitas-aktivitas selama periode waktu tertentu. Dari definisi tersebut, Bernardin menekankan pengertian kinerja sebagai hasil, bukan karakter sifat (trait) dan perilaku. Pengertian kinerja sebagai hasil juga terkait dengan produktivitas dan efektivitas (Ricard dalam Sudarmanto, 2014 : 8). Produktivitas merupakan hubungan antara jumlah barang dan jasa yang dihasilkan dengan jumlah tenaga kerja, modal, dan sumber daya yang digunakan dalam produksi itu (Miner dalam Sudarmanto, $2014: 8$ ).

Kinerja merujuk pengertian sebagai perilaku. Terkait dengan kinerja sebagai perilaku, (Ricard dalam Sudarmanto, 2014 : 8) menyatakan bahwa kinerja merupakan seperangkat perilaku yang relevan dengan tujuan organisasi atau unit organisasi tempat orang bekerja.

Standar kinerja yang efektif didasarkan pada pekerjaan yang tersedia, dipahami, disetujui, spesifik dan terukur, berorientasi waktu, tertulis, dan terbuka untuk berubah. Maka, standar kinerja dapat ditentukan dengan baik dan pekerja termotivasi untuk mencapai atau melebihinya. Untuk itu, pekerja harus dilibatkan dalam menentukan standar. Standar yang baik disusun berdasar kesepakatan bersama sehingga menjadi kontak kinerja yang efektif. Dalam hal terdapat ketidaksepakatan, manajer harus membuat keputusan akhir (Wibowo, 2014 :65).

Tidak ada jumlah standar minimum atau maksimum untuk satu pekerjaan. Dengan mempunyai banyak standar, akan membentuk pekerja memahami lebih jelas apa yang diharapkan dan juga membantu manajer menunjukkan kekuatan spesifik dan bidang yang perlu perbaikan. Manajer dan 
pekerja harus menentukan jumlah standar kinerja yang cocok dan praktis sehingga pelaksanaannya menjadi efektif (Wibowo, $2014:$ 65)

\section{METODE PENELITIAN}

Penelitian ini menggunakan metode deskriptif analisis. Metode deskriptif adalah suatu metode dalam meneliti status kelompok manusia suatu obyek, suatu set kondisi, suatu sistem pemikiran ataupun suatu kelas peristiwa pada masa sekarang. Tujuan penelitian deskriptif ini adalah untuk membuat deskripsi, gambaran atau lukisan secara sistematis, faktual dan akurat mengenai fakta-fakta serta hubungan antar fenomena yang diselidiki. Metoda deskriptif analisis digunakan untuk menguji hipotesis atau menjawab pertanyaan penelitian.

Penggunaan metode deskriptif analitis dalam penelitian ini, adalah untuk mendapatkan gambaran mengenai Motivasi, Budaya Organisasi, dan Kompetensi terhadap Kinerja Karyawan di Politeknik Swasta.

Untuk mengumpulkan data yang akan diolah dan dianalisis, kita perlu menentukan populasi terlebih dahulu. Pengertian populasi menurut Sugiyono (2011 : 61-62) adalah sebagai berikut : "Populasi adalah wilayah generalisasi yang terdiri atas : obyek/subyek yang mempunyai kualitas dan karakteristik tertentu yang ditetapkan oleh peneliti untuk dipelajari dan kemudian ditarik kesimpulannya. Sedangkan sampel adalah bagian dari jumlah dan karakteristik yang dimiliki oleh populasi." Berdasarkan penelitian di atas, yang menjadi populasi dan sampel dalam penelitian ini adalah seluruh karyawan di Politeknik Swasta yang berjumlah 32 orang.

\section{HASIL DAN PEMBAHASAN}

Berdasarkan hasil pengolahan data-data, maka diperoleh gambaran
Motivasi(X1) yaitu dengan rata-rata skor 3,65. Rata-rata skor tersebut sesuai dengan tabel kriteria penafsiran, termasuk kategori Baik. Pernyataan tersebut dinyatakan baik disebabkan karenaSetiap karyawan memiliki kesempatan yang sama dalam promosi jabatan $(4,25)$; Fasilitas kerja yang tersedia membantu saya dalam penyelesaian pekerjaan $(4,22)$ Adapun hasil pengolahan data tentang Motivasi yang memperoleh rata-rata skor terendah adalah Saya selalu mencari informasi dalam bekerja untuk meningkatkan kualitas kerja $(2,88)$; Gaji/upah yang saya terima setiap bulan dapat memotivasi saya untuk bekerja lebih baik $(2,75)$

Sesuai dengan hasil pengolahan data yang dilakukan, diperoleh gambaran Budaya Organisasi (X2) yaitu dengan rata-rata skor 3,11. Rata-rata skor tersebut sesuai dengan tabel kriteria penafsiran, termasuk kategori Cukup Baik.Gambaran Motivasi dikatakan Cukup Baik, diantaranya karena Sebagai karyawan dilembaga ini dituntut untuk mempunyai kreatifitas dalam menyelesaikan pekerjaan $(3,78)$; Sebagai karyawan, saya selalu membangun citra organisasi $(3,69)$.

Adapun hasil pengolahan data tentang Budaya Organisasi karyawan yang memperoleh rata-rata skor terendah adalah :Pimpinan sangat memperhatikan kebutuhan peningkatan keterampilan kerja karyawan (2,69); Pimpinan sangat konsisten dengan diskripsi kerja yang telah ditetapkan $(2,25)$

Berdasarkan hasil pengolahan data-data, maka diperoleh gambaran Kompetensi (X3) yaitu dengan rata-rata skor 3,09. Rata-rata skor tersebut sesuai dengan tabel kriteria penafsiran, termasuk kategori Baik. Pernyataan tersebut dinyatakan baik disebabkan karena Pengetahuan yang saya miliki sangat mendukung dalam pelaksanaan tugas $(3,84)$; Dalam bekerja saya mempunyai cara-cara kreatif yang memudahkan pekerjaan $(3,72)$. 
Jurnal Ilmiah Ekonomi dan Bisnis

Vol. 15. No.1, Maret 2018: 78-83

EISSN : $2442-9813$

ISSN : $1829-9822$

Adapun hasil pengolahan data tentang Motivasi yang memperoleh ratarata skor terendah adalah Keterampilan yang saya miliki masih dapat ditingkatkan dan saya memiliki kemauan untuk belajar $(2,19)$; Saya selalu membaca buku-buku kepustakaan yang berkaitan dengan tugas-tugas saya $(2,16)$ Berdasarkan hasil pengolahan data-data, maka diperoleh gambaran Kinerja (Y) yaitu dengan rata-rata skor 3,59. Ratarata skor tersebut sesuai dengan tabel kriteria penafsiran, termasuk kategori Cukup Baik. Kinerja di Karyawan Politeknik Swasta ini dikatakan baik karenaPara mahasiswa merasa puas dengan pelayanan yang saya berikan $(3,59)$; Keterlambatan datang ke kantor merupakan hal yang tidak baik bagi pribadi saya $(3,47)$.

Adapun hasil pengolahan data tentang Kinerja Karyawan yang memperoleh rata-rata skor terendah adalahKerjasama saya dengan pimpinan selalu berjalan dengan baik $(3,59)$; Hasil yang saya selesaikan selalu sesuai dengan target yang telah di tetapkan oleh pimpinan $(1,94)$

Sesuai dengan hasil pengolahan data yang dilakukan, diperoleh hasil pengaruh Motivasi (X1) terhadap Kinerja (Y) yaitu pengaruh langsung sebesar 0,265 atau $26,5 \%$, pengaruh tidak langsung melalui Budaya Organisasi (X2) sebesar 0,088atau 8,8\%, pengaruh tidak langsung melalui Kompetensi (X3) sebesar 0,112\% atau $11,2 \%$. Dengan demikian pengaruh total sebesar 0,465 atau $10,9 \%$.

Hasil pengolahan data tersebut menunjukkanbahwa terdapat pengaruh Motivasi terhadap Kinerja Karyawan. Dengan demikian terbukti hipotesis yang diajukan dalam penelitian ini, yaitu terdapat pengaruh yang signifikan Motivasi terhadap Kinerja Karyawan

Sesuai dengan hasil pengolahan data yang dilakukan, diperoleh hasil pengaruh Budaya Organisasi (X2) terhadap Kinerja (Y) yaitu pengaruh langsung sebesar 0,058 atau 5,8\%, pengaruh tidak langsung melalui Motivasi (X1) sebesar 0,088 atau $8,8 \%$, pengaruh tidak langsung melalui Kompetensi (X3) sebesar 0,039 atau 3,9\%.Dengan demikian pengaruh total sebesar 0,185 atau $18,5 \%$.

Hasil pengolahan data tersebut menunjukkanbahwa terdapat pengaruh Budaya Organisasi terhadap Kinerja Karyawan. Dengan demikian terbukti hipotesis yang diajukan dalam penelitian ini, yaitu terdapat pengaruh yang signifikan Budaya Organisasi terhadap Kinerja Karyawan.

Sesuai dengan hasil pengolahan data yang dilakukan, diperoleh hasil pengaruh Kompetensi (X3) terhadap Kinerja (Y) yaitu pengaruh langsung sebesar 0,069 atau $6,9 \%$, pengaruh tidak langsung melalui Motivasi (X1) sebesar 0,112atau 11,2\%, pengaruh tidak langsung melalui Budaya Organisasi (X2) sebesar 0,039 atau 3,9\%.Dengan demikian pengaruh total sebesar 0,221 atau $22,1 \%$. Hasil pengolahan data tersebut menunjukkanbahwa terdapat pengaruh Kompetensiterhadap kinerja. Dengan demikian terbukti hipotesis yang diajukan dalam penelitian ini, yaitu yaitu terdapat pengaruh yang signifikan Kompetensi terhadap Kinerja Karyawan

Sesuai dengan hasil pengolahan data yang dilakukan, diperoleh hasil bahwa pengaruh Motivasi (X1), Budaya Organisasi (X2), dan Kompetensi (X3) terhadap Kinerja Karyawan (Y) secara bersama-sama atau simultan memiliki pengaruh total sebesar 0,871 atau $87,1 \%$. Hasil tersebut menunjukkan bahwa pengaruh ketiga variabel tersebut termasuk kategori signifikan.

Hal ini pun sesuai dengan beberapa penelitian sebelumnya yang membuktikan bahwa variabel Motivasi, Budaya Organisasi dan Kompetensi, secara bersama-sama meningkatkan Kinerja Karyawan.

Hal ini menunjukkan bahwa ketiga 
variabel tersebut di atas yaitu Motivasi (X1), Budaya Organisasi (X2), dan Kompetensi secara bersama-sama dan bersinergi dengan baik memiliki pengaruh yang signifikan terhadap Kinerja Karyawan di Politeknik Swasta. Adapun sisanya sebesar 0,129 atau $12,9 \%$ merupakan variabel lain yang tidak diteliti, diantaranya seperti komunikasi intern, kerjasama antar karyawan, pendidikan dan pelatihan, penghargaan atas prestasi, penempatan karyawan, kompensasi, sarana dan prasarana, iklim kerja, dan lain-lain.

\section{KESIMPULAN DAN SARAN}

Berdasarkan hasil penelitian dapat disimpulkan bahwa pengaruh total Kompetensi (X1) terhadap Kinerja Karyawan (Y) sebesar 26,16\%, pengaruh total Motivasi (X2) terhadap Kinerja Karyawan (Y) sebesar 32,40\%, dan total pengaruh Budaya Kerja (X3) terhadap Kinerja Karyawan (Y) sebesar 25,22\%. Sedangkan pengaruh Kompetensi, Motivasi, Budaya Perusahaan terhadap Kinerja secara bersama-sama atau simultan memiliki pengaruh total sebesar $83,79 \%$.

Oleh karenanya untuk meningkatkan kinerja karyawan maka perlu kompetensi, motivasi dan juga budaya kerja yang kondusif.

\section{DAFTAR PUSTAKA}

Arikunto, Suharsimi., 2013. Prosedur Penelitian Suatu Pendekatan Praktik. Jakarta : Rineka Cipta

Mangkunegara,A.A Anwar Prabu., 2008. Evaluasi Kinerja Sumber Daya Manusia. Bandung : Refika Aditama

Marwansyah., 2014. Manajemen Sumber Daya Manusia. Edisi Kedua. Bandung : Alfabeta

Mathis, Robert L. And Jackson, John H., 2009. Manajemen Sumber Daya
Manusia. Edisi 10. Jakarta : Salemba Empat

Robbins, Stephen P. And Judge, Timothy A., 2015. Perilaku Organisasi. Edisi 16. Jakarta: Salemba Empat.

Sarwono, Jonathan., 2014. Riset Skripsi Dan Tesis Dengan Spss 22. Jakarta: Elex Media Komputindo

Sarwono, Jonathan., 2006. Metode Penelitian Kuantitatif Dan Kualitatif. Yogyakarta : Graha Ilmu

Sudarmanto., 2014. Kinerja Dan Pengembangan Kompetensi Sdm. Cetakan Kedua. Yogyakarta : Pustaka Pelajar

Sudjana, Nana., 2010. Tuntunan Penyusunan Karya Ilmiah. Cetakan Ketigabelas. Bandung : Sinar Baru Algensindo

Sugiyono., 2011. Metode Penelitian Kuantitatif Kualitatif Dan $R \& D$. Bandung : Alfabeta

Sule, Ernie Tisnawati. Dan Saefullah, Kurniawan., 2012. Pengantar Manajemen. Edisi Pertama. Cetakan Keenam. Jakarta : Kencana

Wibowo., 2014. Manajemen Kinerja. Cetakan Keempat. Jakarta : Pt. Raja Grafindo Persada

Wibowo., 2014. Perilaku Dalam Organisasi. Cetakan Kedua. Jakarta : Pt. Raja Grafindo Persada Wibowo., 2013. Budaya Organisasi : Sebuah Kebutuhan Untuk Meningkatkan Kinerja Jangka Panjang. Cetakan Ketiga. Jakarta : Pt. Raja Grafindo Persada 